\title{
Age Specific Sensitivity of the Nematode Aphelenchus avenae to Mercury Toxicity
}

\author{
J. A. Camargo, ${ }^{1}$ G. Nombela ${ }^{2}$ M. Muñiz, ${ }^{2}$ A. Navas ${ }^{3}$
}

${ }^{1}$ Área de Ecología, Universidad de Alcalá 28871 Alcalá de Henares, Madrid, Spain

${ }^{2}$ Centro de Ciencias Medioambientales, C.S.I.C., Serrano 115 dpdo., Madrid, Spain

${ }^{3}$ Museo de Ciencias Naturales, C.S.I.C., José Gutierrez Abascal 2, 28006 Madrid, Spain

Received: 18 November 1997/Accepted: 3 June 1998

Although one of the ultimate goals of ecotoxicology is to predict the effects of chemical substances and compounds on whole communities and ecosystems, it is generally accepted by ecotoxicologists that single-species toxicity tests may provide an adequate first step toward the ecological risk assessment of pollutants in soil and water. Consequently, several toxicity tests (ASTM 1993) have been developed and standardized using single species such as Selenastrum capricornutum (freshwater alga), Daphnia magna (freshwater cladoceran), Mytilus edulis (blue mussel) and Oncorhynchus mykiss (rainbow trout). Nevertheless, some groups of organisms have seldom been used in single-species toxicity tests, despite the fact that such organisms can play a significant role in the functional organization of ecosystems. This is the case of the phylum Nematoda (see Kammenga et al. 1996), which contains many species showing a great variety of life cycles and feeding habits. Furthermore, terrestrial nematodes usually are very abundant and important for nutrient cycling (Freckman 1988), living in the soil pore water and therefore being in close contact with the bioavailable concentration of potential pollutants (Houx and Aben 1993).

Mercury $(\mathrm{Hg})$, on the other hand, is a mobile and persistent heavy metal that becomes more concentrated as it is passed through the food chains of ecosystems (Moriarty 1990). Unfortunately, the concentrationof mercury in many soils and surface waters is now increasing as a consequence of human activities (Nriagu and Pacyna 1988; Lindqvist 1991; Swain et al. 1992; Watras 1994; Porcella et al. 1995). This global pollution problem is not due simply to single $\mathrm{Hg}$ discharges, but it is primarily due to widespread $\mathrm{Hg}$ emissions to the atmosphere and their subsequent global distribution; the major sources of $\mathrm{Hg}$ emissions to the atmosphere appear to be chlor-alkali factories, waste incineration plants, coal and peat combustion units, and metal smelter industries. However, in spite of the current trend toward higher concentrations of mercury in the global environment, relatively little is known about the tolerance of terrestrial and aquatic organisms to mercury toxicity (Moriarty 1990; Watras 1994).

The present article describes a set of laboratory experiments that were conducted to examine the short-term toxicity of mercury to juveniles and adults of the nematode Aphelenchus avenae. This fungivorous nematode has been considered to be an ideal biomonitoring agent because of its ability to colonize most edaphic environments and because it is relatively easy to grow and reproduce in the laboratory (Barnes et al. 1981; Mendis and Evans 1983; Navas et al. 1992). 


\section{MATERIALS AND METHODS}

Juveniles and adults of the nematode Aphelenchus avenae Bastian were obtained from a stock culture that had been kept in our laboratory for more than one year. This culture of fungivorous nematodes was maintained in Potato Dextrose Agar (PDA) using Rhizoctonia solani Kühn, a soil-inhabiting fungus common to many edaphic environments (Caubel et al. 1981). The average temperature of the stock culture was $21{ }^{\circ} \mathrm{C}$. Nematodes were not fed during mercury toxicity bioassays.

Renewal short-term toxicity bioassays were conducted in triplicate for 8 days using small glass vessels, with $5 \mathrm{~mL}$ of Madrid dechlorinated tap water per vessel. A control and five different nominal concentrations of mercury $(0.1,0.8,1.5,3.0$, and $6.0 \mathrm{mg} / \mathrm{L}$ ) were used; nominal mercury concentrations were made from mercury chloride $\left(\mathrm{HgCl}_{2}\right.$, Merck, Germany). To introduce nematodes into test vessels, a small portion of the stock culture was homogenized in a $100 \mathrm{~mL}$ water column and then one $\mathrm{mL}$ of this homogeneous portion of the stock culture was used per vessel. The number of nematodes in the controls and each nominal mercury concentration varied from 32 to 79 individuals for juveniles and from 10 to 51 individuals for adults. Toxicity bioassays were carried out at a $\mathrm{pH}$ of 7.0 and a constant temperature of $21{ }^{\circ} \mathrm{C}$ in the dark to optimize environmental conditions. Dead nematodes were removed every day using an optical microscope.

The 48, 72, 96, 120, 144, 168 and 192-hr LC50s were estimated using a personal computer program (Muñiz and Gil 1990). This program estimates lethal concentrations on the basis of probit analysis (Finney 1971). Because some mortality was observed in control vessels, toxicity data were corrected with Abbott's formula (API-IA 1989). In addition, safe concentrations, as 192-hr LC0.01s, were estimated using the same computer program; because there is no probit value for 0\% response (Finney 1971), the probit value of 1.281 for $0.01 \%$ response was chosen as the best approximation to estimate safe concentrations.

\section{RESULTS AND DISCUSSION}

Mortality percentages during mercury toxicity bioassays are showed in Figure 1. It is evident that juveniles exhibited higher mortality percentages than adults, though differences tended to decrease with mercury concentration and exposure time. The 48, 72, 96, 120, 144, 168 and 192-hr LC50 values are presented in Table 1. In all cases, estimated LC50 values for juveniles were higher than those for adults. However, lower 95\% confidence limits of LC50 values for adults and higher $95 \%$ confidence limits of LC50 values for juveniles overlaped. This fact indicates that the differential sensitivity to mercury toxicity between adults and juveniles of the nematode Aphelenchus avenae is not too extreme. In the case of safe concentrations (192-hr LC0.01s), juveniles had lower values than adults (Table 1).

According to published data, the nematode Aphelenchus avenae appears to be either more or less sensitive to mercury toxicity than other species. On the one hand, 96-hr CL50 values for three aquatic-insect taxa (Acroneuria sp., Ephemerella sp. and Hydropsyche sp.) were found to be $2.00 \mathrm{mg} \mathrm{Hg} / \mathrm{L}$ (Warnick and Bell 1969). On the other hand, the acute toxicity to rainbow trout ranges from $0.042 \mathrm{mg}$ $\mathrm{Hg} / \mathrm{L}$ after 4 days (Wobeser 1975) to $1.00 \mathrm{mg} \mathrm{Hg} / \mathrm{L}$ after 25 days (Boetius 1960). The 96 and 168-hr LC50 values for juvenile fathead minnows (Pimephales promelas) were found to be 0.168 and $0.074 \mathrm{mg} \mathrm{Hg} / \mathrm{L}$, respectively (Snarski and Olson 1982). The 48-hr LC50 value for the tubificid worm Tubifex tubifex was 


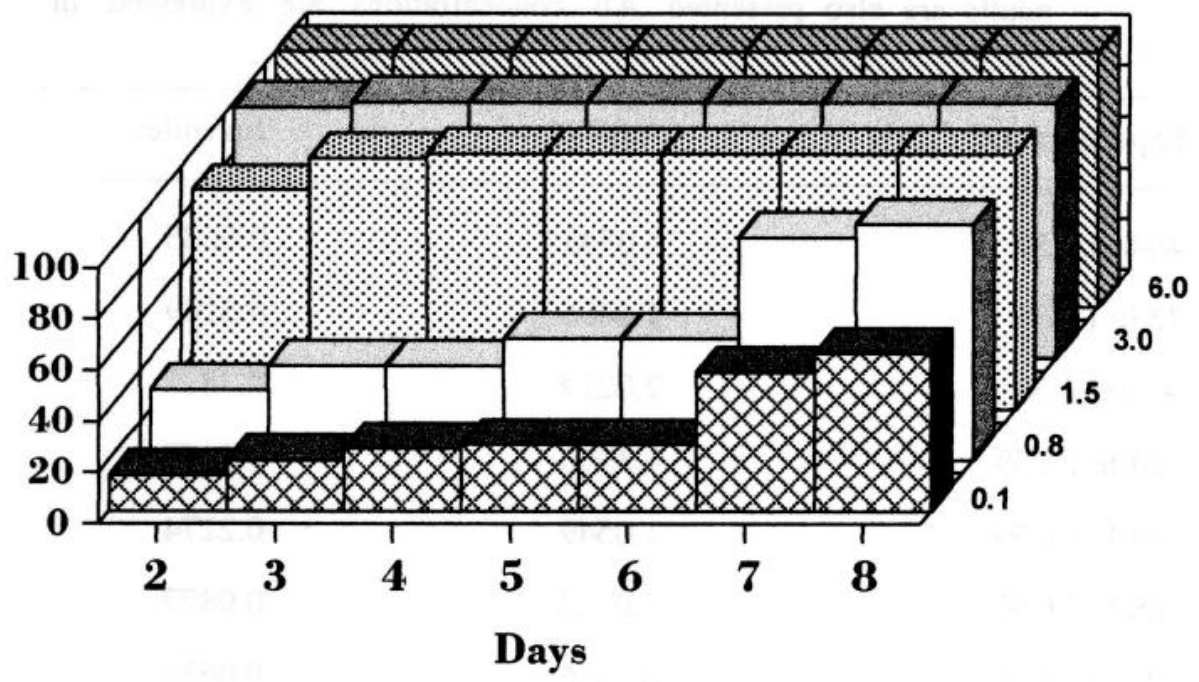

Adults

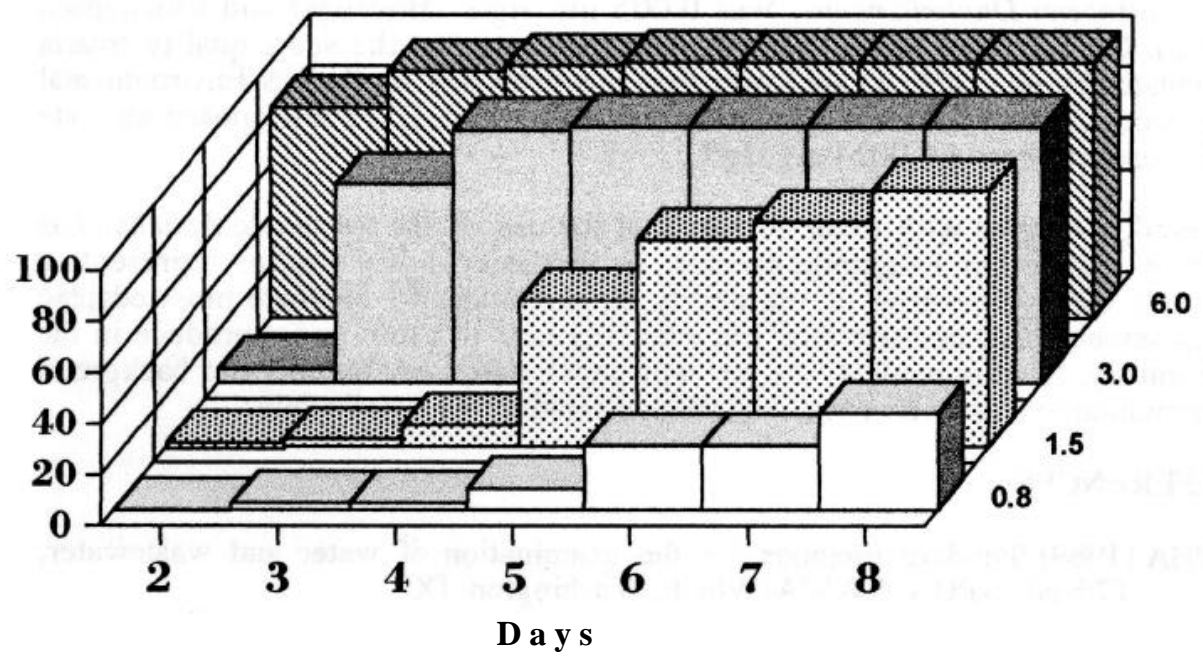

Figure 1. Mortality percentages for juveniles and adults in toxicity bioassays. Concentrations were $0.1,0.8,1.5,3.0$ and $6.0 \mathrm{mg} \mathrm{Hg} / \mathrm{L}$; no mortality was observed for adults at a concentration of 0.1 . 
Table 1. The 48, 72, 96, 120, 144, 168 and 192-hr LC50 values for adults and juveniles. Safe concentrations (192-hr LC0.01s) for juveniles and adults are also presented. All concentrations are expressed in $\mathrm{mg} \mathrm{Hg} / \mathrm{L}$.

\begin{tabular}{lll}
\hline Exposure time & Adults & Juveniles \\
\hline 48-hr LC50 & 4.6543 & 0.6685 \\
$72-$ hr LC50 & 2.4800 & 0.5189 \\
$96-$ hr LC50 & 2.0219 & 0.4817 \\
$120-$ hr LC50 & 1.3900 & 0.3950 \\
$144-h r$ LC50 & 1.0549 & 0.2274 \\
$168-h r$ LC50 & 1.0128 & 0.0877 \\
192-hr LC50 & 0.3356 & 0.0638 \\
192-hr LC0.01 & 0.0019 & 0.0003 \\
\hline
\end{tabular}

$0.08 \mathrm{mg} \mathrm{Hg} / \mathrm{L}$ (Brkovic-Popovic and Popovic 1977), and the 48-hr LC50 value for the crustacean Daphnia magna was $0.005 \mathrm{mg} \mathrm{Hg} / \mathrm{L}$ (Biesinger and Christensen 1972). On the other hand, it is interesting to note that the acute quality criteria calculated by us (Table 1) are lower than that proposed by the US Environmental Protection Agency for fresh aquatic life (USEPA 1986); USEPA proposed an acute safe concentration of $0.0024 \mathrm{mg} \mathrm{Hg} / \mathrm{L}$.

Overall, we agree with other authors that the use of the nematode Aphelenchus avenae, and other nematode species, in ecotoxicological studies represents a suitable method because of the ability of nematodes to colonize most edaphic environments and because they are relatively easy to grow and reproduce in the laboratory. In this respect, the present paper can contribute to the backgroud information for future ecotoxicological investigations with nematodes.

\section{REFERENCES}

APHA (1989) Standard methods for the examination of water and wastewater, 17th ed. APHA-AWWA-WPCF, Washington, DC

ASTM (1993) Aquatic toxicology and hazard evaluation. American Society for Testing and Materials, Philadelphia

Barnes GL, Rusell CC, Foster WD, McNew RW (1981) Aphelenchus avenae, a potential biological control agent for root rot fungi. Plant Dis 65: 423-424

Biesinger KE, Christensen GM (1972) Effects of various metals on survival, growth, reproduction and metabolism of Dapnia magna. J Fish Res Bd Can 29: 1691-1700.

Boetius J (1960) Lethal action of mercury chloride and phenylmercuric acetate on fishes. Medd Dan Fisk Havunders 3: 93-115 
Brkovic-Popovic I, Popovic M (1977) Effects of heavy metals on survival and respiration rate of tubifid worms. Part I. Effects on survival. Environ Pollut 13: $65-72$

Caubel G, Jonan G, Quenerve P, Raowan J (1981) Lutta contre Rhizoctonia solani Kühn, parasite du cottonier par le nematode Aphelenchus avenae Bastian. Rev Nematol 4: 95-98

Finney DJ (1971) Probit analysis, 3rd ed. Cambridge University Press, London

Freckman DW (1988) Bacterivorous nematodes and organic-matter decomposition. Agr Ecosyst Environ 24: 195-217

Houx NWH, Aben WJM (1993) Bioavailability of pollutants to soil organisms via the soil solution. Sci Total Environ Suppl 1: 387-395

Kammenga JE, Van Koert PHG, Riksen JAG, Korthals GW, Bakker J (1996) A toxicity test in artifical soil based in the life-history strategy of the nematode Plectus acuminatus. Environ Toxicol Chem 15: 722-727

Lindqvist O (ed) (1991) Mercury in the Swedish environment. Water Air Soil Pollut 55: 1-261

Mendis AHW, Evans AAF (1983) Population development and oxygen consumption of three isolates of Aphelenchus avenae (Nematoda: Aphelenchidae). Nematologica 29: 309-322

Moriarty F (1990) Ecotoxicology, 2nd ed. Academic Press, London

Muñiz M, Gil A (1990) Relaciones dosis respuestas: Acción conjunta de tóxicos. Ediciones CSIC, Madrid

Navas A, Molinari S, Nombela G, Mundo-Ocampo M (1992) Relationship between population structure and respiration activity in Aphelenchus avenae. Nematol Medit 20: 105-112

Nriagu JO, Pacyna JM (1988) Quantitative assessment of worldwide contamination of air, water and soils by trace metals. Nature 333: 134-139.

Porcella D, Huckabee J, Wheatley B (eds) (1995) Mercury as a global pollutant. WaterAir Soil Pollut 80: 1-1336

Snarski VM, Olson GF (1982) Chronic toxicity and bioaccumulation of mercury chloride in the fathead minow (Pimephales promelas). Aquat Toxicol 12: 143-156.

Swain EB, Engstrom DR, Brigham ME, Henning TA, Brezonik PL (1992) Increasing rates of atmospheric mercury deposition in midcontinental North America. Science 257: 784-787

USEPA (1986) Quality criteria for water. US Environmental Protection Agency, Washington, DC

Warnick SL, Bell HL (1969) The acute toxicity of some heavy metals to different species of aquatic insects. J Wat Pollut Control Fed 41: 280-284

Watras CJ (ed) (1994) Mercury pollution: Integration and synthesis. Lewis Publishers, Boca Raton (Florida)

Wobeser G (1975) Acute toxicity of methyl mercury chloride and mercuric chloride for rainbow trout (Salmo gairdneri) fry and fingerlings. J Fish Res Bd Can 32: $2005-201$ 